Citation: Yavuz Aksakal, N., Career Capital as a Component Human Capital: A Theoretical Model Proposal to The Intellectual Capital, BMIJ, (2020), 8(5): 3772-3794 doi: http://dx.doi.org/10.15295/bmij.v8i5.1656

\title{
CAREER CAPITAL AS A COMPONENT HUMAN CAPITAL: A THEORETICAL MODEL PROPOSAL TO THE INTELLECTUAL
} CAPITAL

Nihan YAVUZ AKSAKAL ${ }^{1}$

\author{
Received Date (Başvuru Tarihi): \\ Accepted Date (Kabul Tarihi): \\ Published Date (Yayın Tarihi):
}

$26 / 10 / 2020$

$2 / 12 / 2020$

$25 / 12 / 2020$
In this study, the concept of intellectual capital and its components are examined first. Then, the standard features of intellectual capital and human capital with career capital are revealed. Moreover, finally, a new model has been proposed for the concept of intellectual capital. The study aims to show the bond of career capital in intellectual capital and to emphasise that it can be considered as a separate essential element. The theoretical model proposed by the study considered career capital as a sub-component of human capital within intellectual capital. Accordingly, human capital in the study consists of two main subcomponents: attitude capital and career capital. The career capital supported by the attitude capital of the human can be evaluated as the whole capital in a concrete career life rather than the individual characteristics of the employee. The study aims to bring a different perspective to studies on the subject. It is the review of the related conceptual literature in order to contribute to the information in the relevant literature.

M10, M12, M19

\section{İNSAN SERMAYESINIIN BİR BİLEŞENI OLARAK KARİYER SERMAYESİ: ENTELEKTÜEL SERMAYEYE İLİŞKİN BİR MODEL ÖNERİİ}

$\ddot{O Z Z}$

\section{Anahtar Kelimeler:}

Kariyer Sermayesi,

Entelektüel Sermaye,

Insan Sermayesi

JEL Kodlart:

M10, M12, M19
Bu çalışmada entelektüel sermaye kavramı ve bileşenleri incelenerek kariyer sermayesi ile ortak özellikleri ortaya konulmuş ve entelektüel sermaye kavramına yeni bir model önerisi sunulmuştur. Çalışmanın amacl, kariyer sermayesinin entelektüel sermaye içerisindeki bağını göstermek ve ayrı bir temel unsur olarak ele alınabileceğini vurgulamaktır. Çalışmanın önerdiŏi kuramsal model kariyer sermayesini entelektüel sermaye içerisinde insan sermayesinin ise bir alt bileşeni olarak ele almıştır. Buna bağh olarak çalışmada insan sermayesi bireysel/tutum sermayesi ve kariyer sermayesi iki temel alt bileşen olarak ele alınmıştır. Insanın bireysel sermayesinden desteklenen ve birikerek büyüyen kariyer sermayesi, çalışanın bireysel özelliklerinden ziyade somut bir kariyer yaşamı içerisinde yer alan sermayenin tamamı olarak değgerlendirilebilmektedir. Çalışma, konuya yönelik çalışmalara farklı bir bakış açısı kazandırarak ilgili literatürdeki bilgi birikimine katkı sağlamak amacılla hazırlanmamı olup ilgili kavramsal literatürün bir taraması niteliğindedir.

\footnotetext{
${ }^{1}$ Arş. Gör., İstanbul Ticaret Üniversitesi, nyavuz@ticaret.edu.tr,
}

https:// orcid.org/0000-0002-1603-2520 


\section{INTRODUCTION}

Capital is one of the factors of production that organisations need to create and maintain their existence. In addition to material resources such as fixtures, tools and raw materials, resources such as knowledge, skills, experience and business knowledge of employees are intangible resources. The cornerstone of intangible resources is "knowledge". Knowledge, taking the place of labor and capital, which are factors of production, quickly becoming the only factor of production (Drucker, 1993: 18) Especially "information", which has become necessary in creating competitive advantage, has strategic importance when used effectively, efficiently and correctly. Organisations with similar raw materials and production conditions differ because of the "human resources" they have. Issues such as knowledge, skills, talents, career, experience, creativity, innovation and entrepreneurship possessed by human resources enable organisations to make different productions using the same raw materials and to stand out. For this reason, the most critical resources of our time that organisations have and give themselves a competitive advantage are human resources from intangible sources and therefore "information". All intangible resources created by knowledge and the value creation of knowledge create intellectual capital.

According to Choo and Bontis (2002), intellectual capital describes existing knowledge in an organisation. It is the sum of all factors that create a competitive advantage for an organisation. Intellectual capital is the company's information assets and is related to how these assets will change over time (Engelman et al.2015). In other words, it is the re-evaluation of knowledge. Intellectual capital ensures the integration of intangible values for all functions and departments of the organisation with a strategic vision.

Over time, different classifications have been made regarding the issue of intellectual capital (Edvinsson and Malone, 1997; Stewart, 1997; Kaplan and Norton, 1993; Roos and Roos 1997; Edvinsson, 1997; Knight 1999; O'Donnell and O'Regan 2000; McElroy 2002). Human capital and structural capital (Edvinsson and Malone, 1997); human capital, structural capital and relational capital (Saint-Onge, 1996); employee competencies, internal capital and external capital (Sveiby, 1997); human capital, 
innovation capital, process capital and customer capital (Van Buren, 1999) are some of those classifications (Tseng and Goo, 2005: 191). The different elements of intellectual capital mentioned above can transform and support each other by being affected by each other in time.

The increase in the education levels of individuals and the changes in their career expectations have brought different dimensions to their career understanding and perspectives. Furthermore, this situation has brought new qualifications to the subject of career. Individual-oriented career approach, boundaryless career concept, individuals' taking the initiative in their careers, knowledge and competence gaining importance, career guidance shifting towards individuals, flexibility, knowledge transfer, the importance of knowledge-based power (Özdemir, 2013) topics such as "career" makes the issue more critical. At this point, it becomes essential for individuals to accumulate all their gains in their careers and make them capital. According to Lamb and Sutherland (2010), career capital is the collection of all knowledge, skills, work experiences, achievements and relationships of an individual and consists of the sum of them at different career levels.

This study aims to redefine the concept of human capital by including the career capital dimension. By examining the concept of intellectual capital and its components, its standard features with career capital have been revealed, and a new model has been proposed to the concept of intellectual capital. Today, career has become more critical, especially with the increase in education level and career opportunities. The career, which requires great effort and investment and consists of a significant accumulation, has become a separate capital that will contribute to the individual. The study has been carried out with the idea that career capital can be handled as a separate fundamental element, especially with changing career understanding. The study aims to contribute to career capital and intellectual capital studies through a different perspective, new classification and a new model. 


\section{LITERATURE REVIEW}

\subsection{Intellectual Capital}

Intellectual capital, first used by Galbraith is, in short, knowledge and dynamic capital with the potential to create value (Edvinsson and Sullivan, 1996: 357-358). Intellectual capital consists of assets that can provide financial returns, such as knowledge, experience, organisation technology, professional experience, customer relations, designs, data processes that provide a competitive advantage (Edvinsson, 1997: 368). The basis of intellectual capital is intellectual property, which consists of components of knowledge. Intellectual capital is an organised and integrated community of knowledge, but what is important here is the ability of the organisation to use intellectual capital (Edvinsson, 1997; Edvinsson and Sullivan, 1996: 357).

The definitions and descriptions of intellectual capital made by various authors are as follows (Table 1).

Looking at the definitions of intellectual capital made by different researchers, many of them have in common the concepts of "value creation", "knowledge" and "non-financial". If we combine all these concepts, we can say that intellectual capital is non-financial resources that create knowledge and value. 


\section{Table 1. The Definitions and Descriptions of Intellectual Capital}

\begin{tabular}{|c|c|c|}
\hline Researcher(s) & Year & Definition of Intellectual Capital \\
\hline Hall & 1992 & $\begin{array}{l}\text { Intellectual capital, which is directly associated with creating a competitive } \\
\text { advantage, is the driving force that converts resources into value-added } \\
\text { tangible assets. }\end{array}$ \\
\hline Stewart & 1997 & $\begin{array}{l}\text { It is information that transforms raw materials and creates more value. It } \\
\text { refers to abilities, knowledge, relations with customers and knowledge } \\
\text { formed by organisational processes. }\end{array}$ \\
\hline Wiig & 1997 & $\begin{array}{l}\text { Organisations consist of financial capital and everything else. What is meant } \\
\text { by "everything else" is intellectual capital? Everything else; It consists of } \\
\text { knowledge, learning, production, creation and relationships. It focuses on } \\
\text { renewing and maximising the value of the intellectual assets of the } \\
\text { organisation. }\end{array}$ \\
\hline $\begin{array}{l}\text { Nahapiet and } \\
\text { Ghoshal }\end{array}$ & 1998 & $\begin{array}{l}\text { It is the ability to collectively create knowledge, source of knowledge and act } \\
\text { based on knowledge. Also, intellectual capital is a social entity and continues } \\
\text { its development through social relations. }\end{array}$ \\
\hline Ulrich & 1998 & $\begin{array}{l}\text { Intellectual capital, which is vital to the success of the organisation, is the } \\
\text { only significant asset that grows, unlike all other declining assets. }\end{array}$ \\
\hline Bukh et al. & 2001 & $\begin{array}{l}\text { Knowledge, which is the essential raw material of the economy and also the } \\
\text { result, is the primary substance of intellectual capital. Furthermore, for this } \\
\text { reason, intellectual capital consists of knowledge, experience and intellectual } \\
\text { property. }\end{array}$ \\
\hline Tseng and Goo & 2005 & $\begin{array}{l}\text { It is a comprehensive whole that includes assets/values that cannot be } \\
\text { measured directly in the organisation. }\end{array}$ \\
\hline Tan et al. & 2007 & $\begin{array}{l}\text { Intellectual capital, which is usually evaluated by researchers on three } \\
\text { dimensions: human capital, customer capital, and structural capital, also } \\
\text { takes into account the strategic alliance capital dimension, which is the fourth } \\
\text { dimension according to one definition. }\end{array}$ \\
\hline Chahal and Bakshi & 2015 & It is critical resources that create a competitive advantage. \\
\hline Kianto et al. & 2017 & $\begin{array}{l}\text { It is the sum of all intangible and information-related resources that an } \\
\text { organisation uses to create value. }\end{array}$ \\
\hline $\begin{array}{l}\text { Dumay and } \\
\text { Guthrie }\end{array}$ & 2019 & $\begin{array}{l}\text { They are assets that are not recorded on the balance sheet, have little or no } \\
\text { physical assets, but contribute to the financial value of the organisation. }\end{array}$ \\
\hline
\end{tabular}

Source: Combined by the author.

When the concept of intellectual capital is examined, various components have been revealed by different researchers (Table 2). 
Table 2. Intellectual Capital Classifications

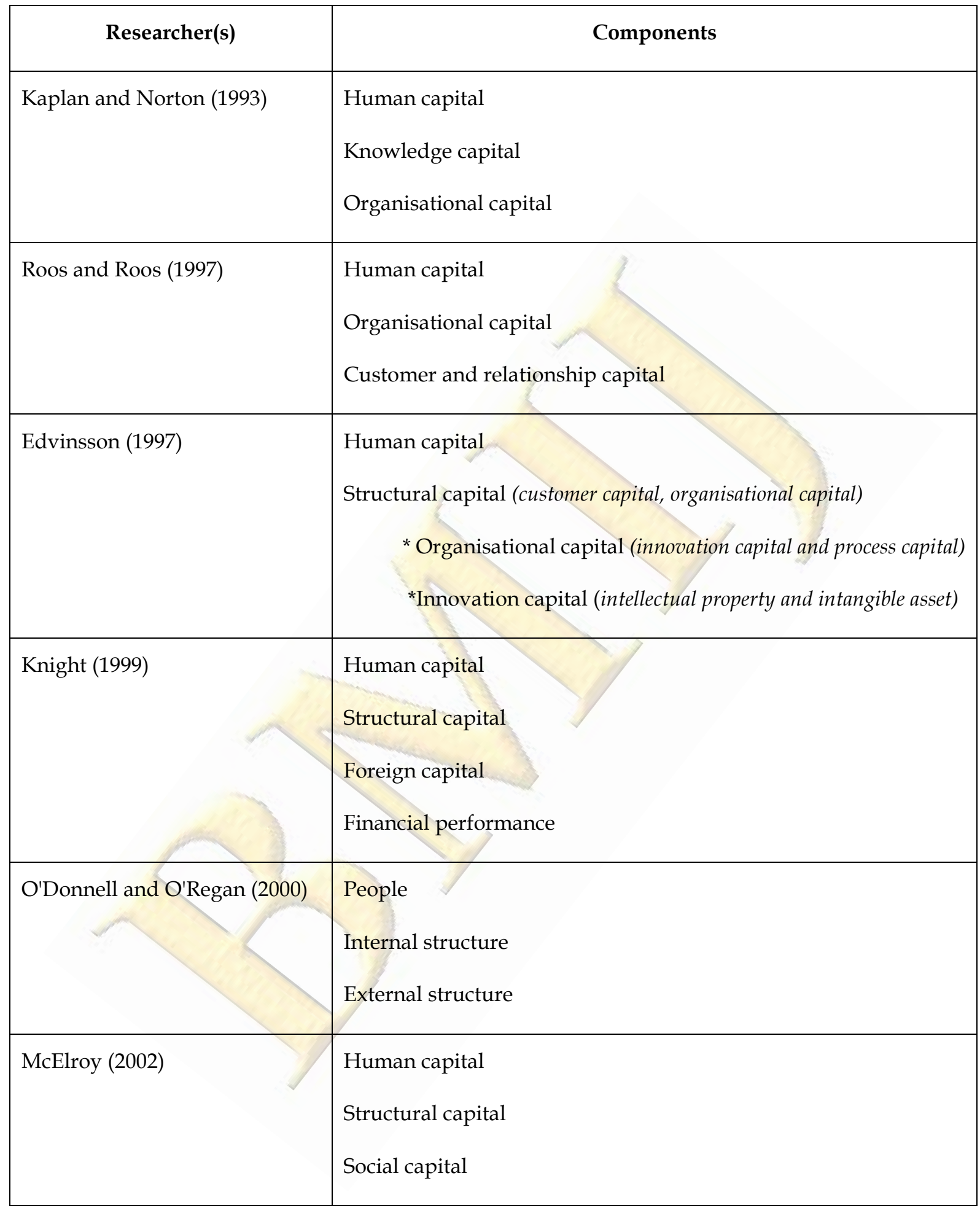

Source: Combined by the author.

In Edvinsson's (1997) study, intellectual capital is under two headings as human capital and structural capital; structural capital is divided into customer capital and organisational capital. However, in the literature, intellectual capital is considered to 
be composed of three components by many researchers. These components; It consists of human capital, structural capital and customer capital. (Bontis et al., 2000).

Human capital is capital consisting of employee information (Edvinsson, 1997). Human capital can also be considered as acquired talents that individuals acquire in their lives and continue as permanent features (David and Lopez, 2001). Human capital, acting together with employees, consists of creativity, teamwork, motivation, loyalty, education, experience, knowledge, skills and talents. Human capital is an essential driving force for the organisation, especially in "value creation" (Bontis et al., 2015). According to a different definition, human capital is the economic value of skill sets, accumulated experiences of employees, and learning capacities (Fang et al., 2009: 473). Human capital, which is described as everything that employees use to create added value, contributes to organisational productivity. It is a resource that arises about how effectively the knowledge, learning, experience, skills, training, and competence of employees are used in order to create organisational value (Chahal and Bakshi, 2015: 379). Human capital brought to the organisation by employees is a significant capital that provides a competitive advantage because it cannot be imitated or substituted by competitors. Human capital is not a tangible and stable asset that the organisation has; when employees leave their jobs, all the characteristics they have, such as knowledge, skills, abilities, education, careers, leave the organisation with them (Elias and Scarbrough, 2004). Human capital, which plays a vital role in increasing individual capacity (Fang et al., 2009), considered by many researchers to be the essential component of intellectual capital. Because organisations may have difficulties in developing new knowledge, making innovation, creating organisational innovation without human resources. It is claimed that human resources management practices are related to human capital and affect structural capital as well (Kianto et al., 2017). Human capital is related to the investments made by the individual and the development of cognitive abilities (Terjesen, 2005). According to another view, human capital theory; it consists of two components: static stock component and dynamic flow component. The static stock component consists of elements such as training knowledge skills; the dynamic flow component includes conscious investments in human capital that increase individual capacity (Fang et al., 2009). Human capital is 
all the intangible gains of employees, and these gains are significant both from the point of view of the organisation and from the point of view of the individual.

As in the work of Jacobsen and Hofman-Bang (2005), human capital can also be studied under two headings: management and employees. According to this view; the employee contributes to the intellectual capital; intellectual capital also contributes to organisational success. Factors such as leadership, communication skills are essential from a management point of view; commitment, motivation, and competencies are essential from an employee's point of view.

Structural capital is another factor of intellectual capital. It concerns the organisational structure and systems that support employee productivity and exist in the organisation (Chahal and Bakshi, 2015: 379). Structural capital is a variety of information treasures such as; organisational culture database of various information, organisational chart, organisational processes, systems, copyrights, methodologies, information technology systems. It reflects all the processes, organisational value, development and renewal value of the organisation (Bontis et al., 2000; Bontis et al., 2015; Stewart, 1997). Structural capital supporting the intellectual capital of the organisation includes complimentary structural systems and infrastructures that ensure efficiency and productivity. Structural capital provides an environment that encourages the human resource's knowledge creation and development process and can consist of both physical and intangible elements. Physical elements include all the physical equipment of the organisation, such as the company building, computers, tools and equipment, while intangible elements consist of information systems, software, working procedures (Edvinsson and Sulivan, 1996: 360). Structural capital, which includes all information stores, creates a collective infrastructure by ensuring the integration of existing information for the organisation (Kianto et al., 2017). Besides; the information obtained from human capital is transformed into structural capital and enables the information management process in the organisation (Stewart, 1997) Jacobsen and Hofman-Bang (2005) divide structural capital into two main topics as intellectual property and processes. Intellectual property consists of patents, trademarks and licenses, while process capital consists of internal processes, marketing models and information systems. In this dimension, it becomes vital to be 
able to transform human capital into structural capital with all intellectual property and process capital.

Customer capital (relationship capital) is a non-financial asset and relationship value consisting of embedded information about marketing channels, customer, competitor, institutions, distribution channels, supplier relationships developed by the organisation. In addition to these relationships, relationships such as employee satisfaction, customer satisfaction, customer loyalty and financial performance are also covered by customer capital. At the same time, human capital and customer capital can contribute to each other. It is claimed that the more competent the human capital, the more customer capital can be developed. Customer capital reveals the potential to benefit from external customer relationships (Bontis et al., 2000; Stewart, 1997; Bontis et al., 2015). Some researchers can also give customer capital the names "relationship capital", "external social capital", "social capital", because of organisations are an open system and consist of relationships and social environment (Jacobsen and HofmanBang, 2005; Kianto et al., 2017). Customer capital, which invests in "innovation", which is an essential issue for organisations, contributes to creating innovation through external relationships. Customer capital based on information, interaction and solidarity from individuals, groups and institutions (Kianto et al., 2017; Adler and Kwon, 2002) is a network of relationships and is the sum of resources that can be developed. It is suggested that this capital has structural, relational and cognitive dimensions (Nahapiet and Ghoshal, 1998). Customer capital is one of the critical factors for the organisation to adopt, implement, develop and gain competitive advantage through its network of relationships (Mehralian et al., 2013: 210). Customer capital has a complex structure, as it contains many living, active and social assets related to the external environment. However, it is crucial for the development and survival of the organisation.

\subsection{Career Capital}

The existence of extreme competitive conditions requires organisations to focus on their core competencies. One of the core competencies that organisations have is "human resources" that cannot be substituted, imitated, unique and rare (Hall, 1992) 
as claimed in the resource-based approach, and employees are among the important factors that create competitive advantage. It is becoming more and more critical for the organisation to ensure the development of employees and to increase their knowledge, skills, experience and abilities. All the characteristics of the employees such as knowledge, skills, experience and abilities constitute their "career capital"; it fills, enriches and shapes their capital. For this reason, career is a crucial point both in the "individual" dimension for the employees and in the "organisational" dimension for the organisations.

Career is all of the work-related experiences individuals have acquired throughout their lives (DeCenzo and Robbins, 2007: 233). According to a different definition, career is the sum of individuals' work experience and skills and embodied knowledge in their working lives (Terjesen, 2005). According to another different view, career is a concept that balances the elements of business and organisation with the values and needs of the individual (Greenhaus, 1987).

Many features such as education levels, experiences, positions, certificates, knowledge, skills, experience, abilities and competencies, sorted in a particular time order throughout the life of the individual, are parts that make up his career. In other words, it is the investments that a person has made in his or her working life. Each piece combines to form a whole and constitutes a capital that can act together with the individual. With the career, the information hidden within the employees is transformed into organisational information.

Career capital, put forward by De Fillippi and Arthur (1994), is the value created on a career through recognition in the external labour market and the internal labour market. According to Lamb and Sutherland (2010), career capital is the collection of all personal qualities, knowledge, skills, work experiences, achievements and relationships of the individual and is obtained by gathering at different career levels. Developing skills, talents and competencies will contribute to career capital by creating career development (Sutherland et al., 2015). Career capital consists of individual resources and relationships related to the individual's career. Career capital is the gathering of an individual's knowledge and experience by superimposing each 
work experience. The employee acts with his/her accumulated experience by adding the knowledge and experience he/she has gained from each work and workplace to his/her existing knowledge and experience. It is the sum of experience accumulated at the individual, organisational and industry level (Inkson and Arthur, 2001).

In Bourdieu's (1986) study on capital, it is argued that symbolic capital is related to the perception and recognition of one's reputation and value and that different types of capital can be transformed (Christian, 2013). From this perspective, career capital can be reconciled with symbolic capital, which Bourdieu (1986) defines as "being known and recognised" and "status". Career capital can also benefit from other types of capital and be transformed. Employees benefit from the combination of economic, social and cultural resources to achieve status. Education, professions, titles, career progression can be instrumental in creating status. Individuals benefit from a significant amount of career capital at this point. Career capital is in motion. It creates marketability by creating value and creates employment opportunities for the individual. In addition to this, while career capital accumulates, it also continues to create opportunities for the individual. The employee can thus have training opportunities, business projects, promotions (Terjesen, 2005).

According to DeFillippi and Arthur (1994), career capital consists of four types. Based on human capital and social capital; it consists of embedded human capital, embedded social capital, embodied human capital and embodied social capital. In the study by DeFillippi and Arthur (1994) on boundaryless career- competency-based perspective, they used the concept of "knowing" in explaining career capital by making use of resource-based and competency-based perspectives.

One of the ways used to explain career capital is based on the concept of "knowing". Knowing-whom, knowing-what, and knowing-why are individual-level elements that makeup career capital (DeFillippi and Arthur, 1994). These elements accumulate by investing and constitute capital. The investments that make up the capital consist of knowledge, skills and abilities (knowing-how), social networks (knowing-whom) and why they work and the energy and motivation (knowing-why) they bring to the business world. All three investments are linked (Inkson and Arthur, 
2001). The career capital, which is related to the competencies of the organisations, is also related to the competencies of the employees. They are all investments that add value to the employees and make them in their career. Employees contribute to human capital along with career self-management and career capital (Alboim et al., 2005).

Knowing-why is related to concepts of career motivation, personal meaning, identification, personality, beliefs, values, goals and interests. Knowing-how is related to professional knowledge, expertise and skills, skills acquired through training. Finally, knowing-whom is related to networks that support relationships, learning and reputation through social capital, and interpersonal relationships (Latzke et al., 2013; Brown and Wond, 2018). In the study conducted by Brown et al. (2020) found that knowing-self consists of self-awareness, self-confidence and motivation; knowinghow consists of "broad, flexible skills", career-related experience, career-related knowledge, technical expertise and qualifications; knowing-who consists of internal and external networks and reputation. Knowing-whom is associated with social capital; knowing-self and knowing-how are related to human capital and cultural capital.

According to Mayrhofer et al. (2002), career capital consists of economic, social and cultural capital and provides direction for an individual's future career. Besides, individuals will be able to become more aware of both their own abilities and career opportunities with all these characteristics. Career capital may vary in different contexts depending on the working environment, it may calculate, it may be portable, and it can be applied to individual growth, including personal development (Brown and Wond, 2018).

Sutherland et al. (2015) revealed 27 career capital components and five groups in their study. These five groups consist of success-oriented personal characteristics, effective interpersonal characteristics, good reputation, flexibility and adaptation, technical skills. When the 27 career capital components were ranked, the top ten were as follows: motivation, determination and perseverance, being known in business and practice, being a part of teamwork, flexibility and adaptability, the ability to establish good relationships with people, the ability to influence, emotional intelligence, 
technical skills, passion for work. It is noted that these characteristics add value to create career capital and create awareness in the individual.

\section{CAREER CAPITAL AS A COMPONENT OF INTELLECTUAL CAPITAL AND HUMAN CAPITAL}

The study aims to provide a new model for intellectual capital. As a method for the development of the model, different studies conducted in different years were subjected to the literature review. Based on this information, a model is suggested.

Different authors have studied intellectual capital according to various approaches. According to Edvinsson and Malone (1997), intellectual capital is seen as necessary in protecting the organisation's value and for individuals to associate their own business with business purposes one to one. In the study by Tseng and Goo (2005: 191), the intellectual capital classification made by various authors was examined. According to this study, intellectual capital is revealed by the combination of different types of capital such as human capital, structural capital, customer capital, relational capital, employee competencies, internal structure, external structure, and innovative capital.

Except for the items of the three (human capital, customer capital and structural capital) generally accepted intellectual capital, innovation capital, organisational capital, process capital, social capital and customer capital of intellectual capital are discussed as components of different dimensions also (Chahal and Bakshi, 2015). It is suggested that new components have been added to the intellectual capital as a result of different studies in addition to three essential components over time. All components put forward by various authors as a result of further research are related to the three basic dimensions of intellectual capital, complementing and supporting each other. In this study, another sub-component has been added to the dimensions of intellectual capital, and career capital is evaluated within human capital, and inferences about this topic are included.

Intellectual capital can be seen as revealing the organisational interaction with the values created by employees through various capitals. At the centre of all these 
capitals is the human element. The interaction of career capital and intellectual capital coincides at many points, as shown below.

- As stated by Edvinsson (1997: 369), while organisations have human capital, they use the knowledge, skills, experience and abilities of employees. However, since organisations cannot have all these concepts directly and cannot evaluate these concepts as an element of physical capital, they use them in a sense by renting them. For example, situations such as leadership are transforming human capital into structural capital. This transformation takes place with the knowledge, skills, experience and abilities of the leader. The employee's career is a subsidiary capital owned. For this reason, just like human capital, it is rented and used by the organisation.

- Changes in intellectual capital can be measured or made visible (Karacan, 2007; Önce, 1999). Career progress, training and performance can be measured. These measurements can also be analysed as numerical data. Based on this, it is possible to convert career capital into measurable or visible.

- In order for an element to be qualified as intellectual capital, it is foreseen to add value to the organisation and must have a competitive edge (Edvinsson, 2002: 208). Intellectual capital has recently been considered as an essential factor for organisations to gain competitive advantage and making a difference (Karacan, 2007; Önce, 1999). Human is the most crucial factor in achieving this competitive advantage and reflects it to the organisation with its knowledge, education, experience, abilities. Each of these elements can only be combined around career. All the savings in career constitute career capital. In this direction, career capital provides a competitive advantage to the organisation, just like the three elements of intellectual capital.

- Management of intellectual capital is an essential managerial responsibility for the organisation (Karacan, 2007; Önce, 1999). Career capital of employees is also an essential element that needs to be developed and managed. Providing opportunities to employees by the organisation, career counselling, promotions, training, and career development are among the critical issues. 
- Intellectual capital is considered the brainpower assets of the organisation. It includes elements such as intellectual property and innovation (Sullivan, 2000). Creating knowledge with the help of brainpower, creativity and innovation and using them as an accumulation in career expands career capital.

From the point of view of all these characteristics of intellectual capital, career capital seems very close to human capital. Even in many classifications, the career element is evaluated within human capital. Dickmann and Harris (2005) stated that although there is an overlap that improving individual career capital will increase organisational human capital, these concepts are not the same. It suggests that researchers prefer to use expressions such as individual and organisational career capital perspectives. Guthrie (2001) considered the elements of human capital like education, professional qualification, business-related knowledge, business competence, entrepreneurial spirit, innovation, proactive and reactive ability, changeability. According to a different distinction, human capital elements consist of talent, relationships and values. This distinction emphasises interpersonal relationships, employee capacity, personal effort and information sharing (Ayas, 2015). According to Roos and Roos (1997), human capital consists of knowledge capital, talent capital, motivation capital and task capital. According to another definition, human capital consists of the use of experience, learning, skills, education, sufficiency and creativity, as well as the sum of attitudes, competence and abilities (Chahal and Bakshi, 2015). As defended by David and Lopez (2001), human capital can be classified into concrete and abstract categories. Concrete features such as longevity, physiological state, health; psycho-motor skills such as ability; Operational abilities such as creativity, problem-solving, leadership, loyalty, trust and cognitive abilities can be classified as abstract features. As in the study of David and Lopez (2001), more "individual" - centred characteristics were referred to within human capital. The objective evaluation of the career as a whole separately from the individual (such as not considering human personality and individual characteristics as career elements) and the creation of a separate "role" and "role requirements" in the life of the individual are among the specific points. Career capital consists of the combination of the individual's education and learning from the environment, and work experience in 
business life brought to the organisation by the employee. Miller and Wurzburg (1995) suggest that human capital is something that employees bring to the organisation and take with them when they leave, but it is developed through training and work experience in the workplace. From this point of view, it is believed that employees come to the organisation with their knowledge, skills, abilities, competence and experience, and take all these elements when leaving; however, they provide the development with training and experience in the organisation, and they do this entirely within the framework of their career. At this point, human capital sheds light on career capital.

Two of the career-enhancing elements are organisation and job opportunities. These elements are blended within the employee, and capital is accumulated for the career. Each of the elements that make up this capital is "knowledge-creating", "valuecreating" and "non-financial" elements and are "business/career" centred. Points such as the education, experience, language proficiency and knowledge of the employees can be considered as non-financial but objective gains. Many features such as the employee's ability, motivation, emotional intelligence, entrepreneurship, creativity, self-confidence, adaptability can be seen as individual-centred intangible gains of the employee. While factors such as education, experience, language competencies, knowledge are directly specific to the "career" that the employee has and developed; factors such as abilities, creativity, self-confidence and motivation are the "individualcentred" capital that the individual provides to the organisation in creating value. Bontis et al. (1999) define human capital as combined intelligence, skills and expertise that can learn, change, innovate and give the organisation its unique character.

In this definition, mostly "characteristics coming from the individual" of human capital are prioritised. According to a study, it was revealed that various human capital factors such as tenure, experience, education are directly related to career success $(\mathrm{Ng}$ et al., 2005). It is argued that human capital refers to individual-level resources that can represent the functional form of career capital (DiRenzo, 2010). According to a study, career capital consists of four components. These components are educational capital, experience capital, entrepreneurial capital and language capital (BarwińskaMałajowicz and Tęcza, 2019). According to this study, career capital consists of 
qualifications that will provide career development rather than individual characteristics coming from the individual. In the light of the researches mentioned above, although career capital is in a correlation with human capital, career element is a more concrete and objective concept and it has sharp aspects that differ from many elements in human capital; it has been concluded that career capital has an important place in human capital and can be qualified as a subcomponent. Intellectual capital creates knowledge and creates value in the organisation, but it is a capital created by all intangible resources as a whole. Human capital, relational capital, structural capital are the elements that enable the emergence of intellectual capital and support intellectual capital from different points. Since career capital is a factor brought to the organisation by the individual and supports human capital and intellectual capital, it is considered as a sub-capital type.

Career capital coincides with many characteristics of intellectual capital components when looking at intellectual capital models. Career capital consists of different elements that can be accumulated cumulatively and used for career success. These elements are supported by economic, cultural and social elements, as well as relationship capital and structural capital. Among all these elements, career capital is mostly associated with human capital; However, since it will be evaluated as a concrete career life rather than the individual characteristics of the employee, it is considered as a sub-component of human capital in this study. For this reason, human capital is considered as two sub-elements in this study as attitude capital and career capital (Figure 1). Concepts such as attitude, skills, behaviours, abilities, personality, health, thinking, creativity, problem-solving, leadership, loyalty is mostly the result of an individual being an "attitude/individual/human"; the career creates concepts such as education, experiences, job-related roles, technical knowledge. As a result, all these components of capital are linked together with the flow of information and create value. A career is a path in which all the characteristics of a person form and go as a result, and career capital is a stock accumulated on the path formed by individual characteristics. 


\section{INTELLECTUAL CAPITAL}

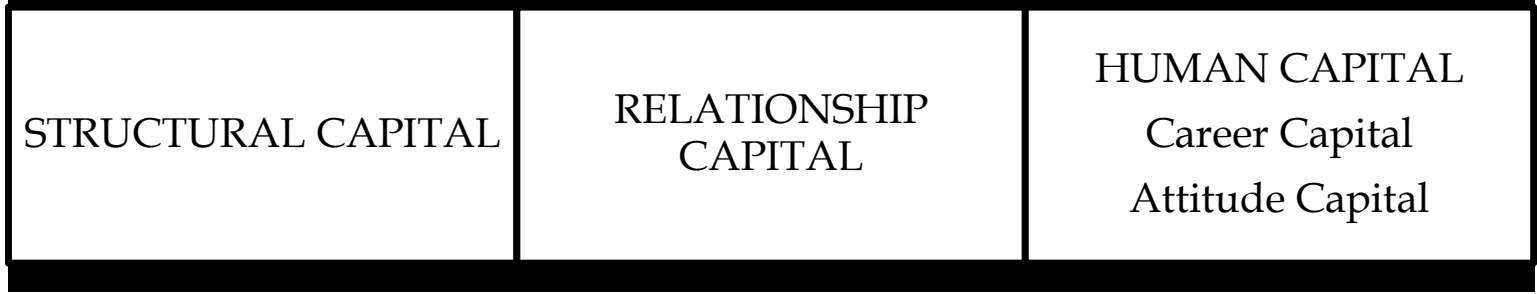

Figure 1. Intellectual Capital Model Proposal

\section{CONCLUSION}

In the information age, we are in, one of the increasingly essential issues is employee knowledge. The focus of employee knowledge and created value is intellectual capital, which is the source of knowledge. From this point of view, the most important of the components that make up intellectual capital is human capital that creates knowledge. According to the generally accepted intellectual capital perspectives, human capital consists of many elements such as career, education, experiences, talent, competence, skill, attitude, behaviour. Among all these elements that create human capital, there is a common point that is influenced by individual characteristics and constitutes future investment: career. The concept of career is formed by the effect of all individual characteristics as well as education, past experiences and continues to grow throughout the working life. It is brought to the organisation by the employee and goes to the organisation with the employee when leaving. In this sense, when human capital is considered as a way, career is always on the road, affecting the past, present and future, and at the same time affecting them and capital. During this whole process, career grows cumulatively and constitutes capital. At the same time, career capital can be objectively evaluated, measured and creates competitive advantage. All these features make it part of the intellectual capital. In the study, it is concluded that career capital has an important place in human capital and can be qualified as a separate subcomponent. For this purpose, a theoretical model proposal is presented by looking at the intellectual capital model, which has been accepted and frequently used in the relevant literature, from a different perspective. Human capital has been examined as two subcomponents. Attitude capital and career capital were laid out. Attitude capital is thought to be related to 
concepts such as attitude, skills, behaviour, abilities, personality, health, thought, creativity, problem-solving, leadership, and loyalty. Career capital is thought to consist of concrete, observable and measurable concepts such as education, experiences, relevant roles, and technical knowledge. The study aims to provide a theoretical contribution in terms of different intellectual capital classifications and a literature review on career capital. It is hoped that the combined evaluation of different studies on intellectual capital and career capital will contribute from the perspective of the literature. It is thought that the study will contribute to the knowledge in the relevant literature by giving a different perspective to the studies on the subject and shed light on future studies. It is suggested that the distinction (attitude capital/career capital) suggested in future studies can be supported by quantitative studies. In future studies, the sub-factors that make up these two different capitals can be put forward in more detail by supporting quantitative data. 


\section{REFERENCES}

Adler, P.S. \& Kwon, S.W. (2002). Social capital: prospects for a new concept, The Academy of Management Review, 27(1), 17-40.

Alboim, N., Finnie, R. \& Meng, R. (2005). The discounting of immigrants' skills in Canada, Evidence and Policy, IRPP Clwices, 11 (1).

Ayas, S. (2015). Entelektüel sermaye ve yenilikçi iş davranışının işletme performansına etkisi: bilişim sektöründe bir uygulama, Çanakkale On Sekiz Mart University, Social Sciences Institute, Master Thesis, Çanakkale.

Barwińska-Małajowicz, A. \& Tęcza, K. (2019). Educational capital as a type of career capital of higher education graduates, Humanities and Social Sciences, 24(26), 7-16.

Bontis, N., Dragonetti, N.C., Jacobsen, K. \& Roos G. (1999). The knowledge toolbox: A review of the tools available to measure and manage intangible resources, European Management Journal, 17, 391-402.

Bontis, N. Janoševi, S. \& Dženopoljac, V. (2015). Intellectual capital in Serbia's hotel industry, International Journal of Contemporary Hospitality Management, 27(6), 1365 -1384.

Bontis, N., Keow, W.C.C. \& Richardson, S. (2000). Intellectual Capital and business performance in malaysian industry, Journal of Intellectual Capital, 1(1), 85-100.

Bourdieu, P. (1986). The forms of capital. In J. Richardson (Ed.), Handbook of theory and research for the sociology of education (pp. 241-258). New York, NY: Greenwood.

Brown, C., Hooley, T. \& Wond, T. (2020). Building career capital: developing business leaders' career mobility, Career Development International.

Brown, C. \& Wond, T. (2018). Building career mobility: A critical exploration of career capital, Journal of the National Institute for Career Education and Counselling, 41(1), 56-63.

Bukh, P.N., Larsen, H.T. \& Mouritsen, J. (2001). Constructing intellectual capital statements, Scandinavian Journal of Management, 17, 87-108.

Chahal, H. \& Bakshi, P. (2015). Examining intellectual capital and competitive advantage relationship, International Journal of Bank Marketing, 33(3), 376 - 399.

Christian, Y. (2013). The perceived value of Chinese expatriates' career capital: a symbolic capital perspective, Journal of Global Mobility, 1(2), 187-218.

Choo, C.W. \& Bontis, N. (2002). The strategic management of intellectual capital and organisational knowledge, New York: Oxford University Press.

David, P. \& Lopez, G. (2001). Knowledge, capabilities and human capital formation in economic Growth, New Zealand Treasury Working Paper, 1 (13). 
DeCenzo, D.A. \& Robbins, S.P. (2007). Fundamentals Of Human Resource Management. U.S.A.: John Wiley \& Sons Inc.

De Fillippi, R. \& Arthur, M. (1994). The boundaryless career: a competency-based perspective, Journal of Organizational Behavior, 15, 307-324.

Dickmann, M. \& Harris, H. (2005). Developing career capital for global careers: the role of international assignments, Journal of World Business, 40(4), 399-408.

DiRenzo, M. S. (2010). An examination of the roles of protean career orientation and career capital on work and life outcomes, PhD Thesis, Drexel University, Philadelphia, USA.

Dumay, J. \& Guthrie, J. (2019). "Reflections on interdisciplinary critical intellectual capital accounting research multidisciplinary propositions for a new future", Accounting, Auditing E Accountability Journal, 32(8), 2282-2306.

Drucker, P.F. (1993). Post-Capitalist Society, Butterworth Heinemann.

Edvinsson, L. (1997). Developing intellectual capital at Skandia, Long Range Planning, 30(3), 366-373.

Edvinsson, L. (2002). Şirket Boylamı. Çev: Ahmet Kardam, İstanbul: Türk Henkel Dergisi Yayınları.

Edvinsson, L. \& Malone, M. S. (1997). Intellectual capital: realising your company's true value by finding its hidden brainpower. New York: Harper Business.

Edvinsson, L. \& Sullivan, P. (1996). Developing a model for managing intellectual capital, European Management Journal, 14(4), 356-364.

Elias, J. \& Scarbrough, H. (2004). Evaluating human capital: an exploratory study of management practice, Human Resource Management Journal, 14(4), 21-40.

Engelman, R, Fracasso, M.E, Neto, M.H. \& Schmidt, S. (2015). The influence of intellectual capital on absorptive capacity and product innovation, EnANPAD, Belo Horizonte, Brazil.

Fang, T., Zikic, J. \& Novicevic, M. M. (2009). Career success of immigrant professionals: stock and flow of their career capital, International Journal of Manpower, 30(5), 472-488.

Greenhaus, J.H. (1987). Career Management. U.S.A.: The Dryden Press.

Guthrie, J. (2001). The management, measurement and the reporting of intellectual capital, Journal of Intellectual Capital, 2(1), 27-41.

Hall, R. (1992). The strategic analysis of intangible resources, Strategic Management Journal, 13(2), 135144.

Inkson, K. \&Arthur, M. B. (2001). How to be a successful career capitalist, Organizational Dynamics, 30(1), 48-61. 
Jacobsen, K. \& Hofman-Bang, P. (2005). IC rating modeli, (Yazan ve Derleyen Dr. Yılmaz Argüden), İstanbul: ARGE Danışmanlık Yayınları, No:7.

Kaplan, R.S. \& Norton, D. P. (1993). Putting the blanced scorecard to work, Harvard Business Review OnPoint Collection, Focusing Your Organisation on Strategy-with the Blanced Scorecard, 2 nd Edition.

Karacan, S. (2007). Entelektüel sermayenin muhasebeleştirilmesi ve finansal tablolarda sunulmast: entelektüel sermayeye muhasebe bilgi sistemi açısından bir yaklaşım, Ankara: Orient Yayınları.

Kianto, A., Sáenz, J. \& Aramburu, N. (2017). Knowledge-based human resource management practices, intellectual capital and innovation, Journal of Business Research, 81, 11-20.

Knight, D.J. (1999). Performance measures for increasing intellectual capital, Strategy \& Leadership, 27(2), 22-27.

Lamb, M., \& Sutherland, M. (2010). The components of career capital for knowledge workers in the global economy, The International Journal of Human Resource Management, 21(3), 295-312.

Latzke, M., Mayrhofer, W., Pernkopf-Konhäusner, K., Rohr, C. \& Schneidhofer, T.M. (2013). Career capital in transitions crossing career fields, EGOS 2013: Bridging Continents, Cultures and Worldviews SWG 1: Rethinking Careers: Theoretical Foundations of Career Studies and their Development, July 46, 2013, Montrèal, Canada.

Mayrhofer, W., Strunk, G., Schiffinger, M., Iellatchitch, A., Steyrer, J. \& Meyer, M. (2002). Career habitus: theoretical and empirical contributions to make a black box gray, Academy of Management Annual Conference.

McElroy, M.W. (2002). Social innovation capital, Journal of Intellectual Capital, 3(1), 30-39.

Mehralian, G., Rasekh, H. R., Akhavan, P. \& Ghatari, A. R. (2013). Prioritisation of intellectual capital indicators in knowledge-based industries: evidence from pharmaceutical industry, International Journal of Information Management, 33, 209-216.

Miller, R. \& Wurzburg, G. (1995). Investing in human capital, The OECD Observer, 193, 16-19.

Nahapiet, J. \& Ghoshal, S. (1998). Social capital, intellectual capital and the organisation advantage, Academy of Management Review, 23(2), 242-266.

Ng, T.W.H., Eby, L.T., Sorensen, K.L. \& Feldman, D.C. (2005). Predictors of objective and subjective career success: a meta-analysis, Personnel Psychology, 58, 367-408.

O'Donnell, D. \& O'Regan, P. (2000). The structural dimensions of intellectual capital: emerging challenges for management and accounting, Southern African Business Review: Special Issue on Information Technology, 4(2), 14-20.

Önce, S. (1999). Muhasebe bakış açısı ile entellektüel sermaye, Eskişehir: T.C. Anadolu Üniversitesi Yayınları. 
Özdemir, Y. (2013). Marmara Bölgesindeki işletmelerin ik yöneticilerinden kariyer anlayışındaki değişime yönelik değerlendirmeleri, Ç.Ü. Sosyal Bilimler Enstitüsü Dergisi, 22(1), 257-274.

Roos, G. \& Roos, J. (1997). Measuring your company's intellectual performance, Long Range Planning, 30(3), 413-426.

Saint-Onge, H. (1996) Tacit knowledge: the key to the strategic alignment of intellectual capital, Strategy E Leadership, 24(2), 10-15.

Stewart, T. (1997). Intellectual capital: the new wealth of organisations, London: Nicholas Brealey.

Sullivan, P. H. (2000). Value-driven intellectual capital: how to convert intangible corporate assets into market value. USA: John Wiley \& Sons.

Sutherland, M., Naidu, G., Seabela, S., Crosson, S. \& Nyembe, E. (2015). The components of career capital and how they are acquired by knowledge workers across different industries, South African Journal of Business Management, 46(4), 1-10.

Sveiby, K.E. (1997) The new organisational wealth: managing and measuring knowledge-based assets. San Francisco: Berrett-Koehler.

Tan, H.P., Plowman, D. \& Hancock, P. (2007). Intellectual capital and financial returns of companies, Journal of Intellectual Capital, 8(1), 76-95.

Terjesen, S. (2005). Senior women managers' transition to entrepreneurship: leveraging embedded career capital, Career Development International, 10(3), 246-259.

Tseng C.Y. \& Goo J.Y.J (2005). Intellectual capital and corporate value in an emerging economy: empirical study of Taiwanese manufacturers", RED Management 35(2), 187-201.

Ulrich, D. (1998). Cambridge intellectual capital = competence $x$ commitment, Sloan Management Review, $39(2), 15-26$.

Van Buren, M.E. (1999) Making knowledge counts: knowledge management systems and the human element, Unpublished manuscript.

Wiig, K.M. (1997). Integrating intellectual capital knowledge management, Long Range Planning, 30(3), 399- 405. 